\section{Production of Fuchsia and Tibouchina Standards Using Paclobutrazol or Chlormequat}

\author{
C.M. Roberts, G.W. Eaton, and F.M. Seywerd \\ Department of Plant Science, The University of British Columbia, \\ Vancouver, B.C. V6T 2A2, Canada
}

Additional index words. Fuchsia x hybrida 'Mantilla', Tibouchina urvilleana, princess flower, glory bush

\begin{abstract}
Paclobutrazol treatments of $0,0.125,0.250$, and $0.500 \mathrm{mg} / \mathrm{plant}$ improved the form of Tibouchina urvilleana (DC.) standards and eliminated the need for pruning during the display season. Paclobutrazol did not improve the form of Fuchsia $\times$ hybrida Hort. ex Vllm. Paclobutrazol inhibited trunk caliper development in both species. Paclobutrazol at $0.125 \mathrm{mg} /$ plant slightly increased Tibouchina flower size. Chlormequat at 0,1000 , or $2000 \mathrm{mg} /$ plant did not hasten flowering of Tibouchina. Chemical names used: $\quad B$-[(4-chlorophenyl) methyl]- $\alpha$ - (1,1-dimethylethyl) -1H-1,2,4-triazole-1-ethanol (paclobutrazol); $\alpha$--chloro-N,N,N-trimethylethanammonium chloride (chlormequat).
\end{abstract}

The ornamental value of plants grown as standards depends on their having a strong, straight trunk and a dense crown. Prolific, early flowering is also desirable. Normally, the standard form is achieved by pruning, although it is often unsightly during the display season and is labor-intensive and delays flowering. The use of growth regulators has improved the quality of some container-grown ornamental (Hentig, 1985; Wainwright and Irwin, 1987)

Paclobutrazol suppresses vegetative growth of Tiboucchina (Roberts and Eaton, 1988; Shanks, 1980) and Fuchsia (Shanks, 1980). It can either delay (Goulston and Shearing, 1985; Wainwright and Irwin, 1987) or hasten (Goulston and Shearing, 1985; Roberts and Eaton, 1988) flowering. Paclobutrazol can reduce flower size (McDaniel, 1986), increase the number of flowers (Shanks, 1980; Wilkinson and Richards, 1987) or inflorescences (Kristensen and Adriansen, 1988), and decrease that of panicles per plant (Roberts and Eaton, 1988). Chlormequat also retards vegetative growth of Tibouchina (Roberts and lateral shoots in some ornamental plants (Hamza and Helaly, 1983). Chlormequat was previously shown to accelerate flowering (Armitage, 1986; Roberts and Eaton, 1988). The present experiment attempted to hasten production and to improve the form and bouchina standards by use of paclobutrazol or chlormequat.

Fuchsia and Tibouchina were propagated from $15-\mathrm{cm}$ tip cuttings under mist and pot-

Received for publication 31 Oct. 1989. Financial support was provided by the Natural Sciences and Engineering Research council of Canada operating grant A2023. The cost of publishing this paper was defrayed in part by the payment of page charges. Under postal regulations, this paper therefore must be hereby marked advertisement solely to indicate this fact. Eaton, 1988) and stimulates production of flowering characteristics of Fuchsia and Ti- ted in 3.2-liter containers on 11 May 1987. The potting medium ( $\mathrm{pH}$ 6.6) was sterilized sandy loam containing $10 \%$ peatmoss by volume. Osmocote (14N-6.2P-11.6K) was added at $20 \mathrm{~g} /$ pot. A $20 \mathrm{~N}-8.7 \mathrm{P}-16.6 \mathrm{~K}$ watersoluble fertilizer (W.R. Grace \& Co., Fogelsville, $\mathrm{Pa}$.) was applied at the rate of 2.4 $\mathrm{g} \cdot$ liter $^{-1}$ every second week during routine watering. The temperature range in the greenhouse was from 20 to $30 \mathrm{C}$.

In the first year, plants were staked and trained to a single leader and sorted by size into seven randomized complete blocks of Fuchsia and 12 blocks of Tibouchina. In each species, there were four treatments per block. At the time of treatment, Fuchsia were 46 to $68 \mathrm{~cm}$ high and Tibouchina 37 to $93 \mathrm{~cm}$. The height of each plant was marked and laterals arising below the mark were removed. Subsequent growth formed the crown. Paclobutrazol was applied on 13 May as an aqueous soil drench at rates of $0,0.125$, 0.250 , or $0.500 \mathrm{mg}$ a.i. in $200 \mathrm{ml}$ of water per pot. Plant height was recorded every other week from 19 May through 6 Aug. The number of Fuschia flowers per plant and their average weight and petal length were recorded and removed weekly from 4 June to 6 Aug. Petal length and days to anthesis were recorded for the first Tibouchina flowers, and the panicles on each plant were counted 11 Aug.
Plants were repotted into 7.3-liter containers on 31 Aug., and each crown was pruned to a $15-\mathrm{cm}$ radius. A second soil drench of paclobutrazol was applied at the same rates as before. Plants were harvested 3 Nov., and trunk caliper was measured 2.5 $\mathrm{cm}$ above the soil. In Fuchsia, the number of primary and secondary branches and the total length of primary growth were recorded. In Tibouchina, the number of secondary and tertiary branches and the total length of secondary growth were recorded. Crown density was computed in Tibouchina as the number of tertiary laterals per meter of secondary branch and in Fuchsia as the number of secondary laterals per meter of primary branch.

In the second year, the untreated Tibouchina standards from the previous experiment had attained trunk heights of 50 to $93 \mathrm{~cm}$ and were repotted into 19.5-liter containers on 29 Feb. 1988. The plants were sorted by size into seven new randomized complete blocks with three treatments per block. The crowns were pruned to a 20 - to $25-\mathrm{cm}$ radius on 17 Mar. We refer to the secondary new growth, which arose on these crowns after pruning, as branches and the further tertiary shoots as laterals. Treatments of 0,1000 , or $2000 \mathrm{mg}$ a.i. chlormequat in $360 \mathrm{ml}$ of water per plant were applied as a soil drench on 22 Mar. Data recorded in mid-July included height, caliper $5 \mathrm{~cm}$ above the soil, petal length, total length and number of branches, the total number of laterals, and the number of days from treatment to anthesis.

Application of paclobutrazol retarded growth of both Tibouchina and Fuchsia (Table 1). A significant linear effect $(P=0.01)$ was first detected 5 weeks after treatment in both species. Paclobutrazol application increased crown density of Tibouchina, but not that of Fuchsia (Table 2). Caliper affects both appearance and strength of a standard and is a criterion of marketability. Paclobutrazol reduced caliper of both species (Table 2), resulting in an undesirable lengthening of the production period. Treatment should be delayed until the caliper is satisfactory. Chlormequat retarded growth of Tibouchina standards and increased crown density, but had no significant effect on caliper or number of laterals (Table 3 ).

Unlike in a previous study (Roberts and Eaton, 1988), the number of days between treatment and flowering was not affected by paclobutrazol or chlormequat in Tibouchina
Table 1. Effect of one soil drench application (13 May 1987) of paclobutrazol on height of Tibouchina and Fuchsia standards.

\begin{tabular}{|c|c|c|c|c|}
\hline \multirow{3}{*}{$\begin{array}{l}\text { Paclobutrazol } \\
(\mathrm{mg} / \mathrm{pot})\end{array}$} & \multicolumn{4}{|c|}{ Weeks after treatment } \\
\hline & \multicolumn{2}{|c|}{5} & \multicolumn{2}{|c|}{11} \\
\hline & Tibouchina & Fuchsia & Tibouchina & Fuchsia \\
\hline & \multicolumn{4}{|c|}{ Height $(\mathrm{cm})$} \\
\hline 0.000 & 79 & 90 & 87 & 105 \\
\hline 0.125 & 79 & 92 & 83 & 104 \\
\hline 0.250 & 75 & 89 & 76 & 95 \\
\hline 0.500 & 72 & 79 & 73 & 83 \\
\hline Significance $^{2}$ & $\mathrm{~L}$ & $\mathrm{~L}$ & $\mathrm{~L}$ & L \\
\hline
\end{tabular}

${ }^{2} \mathrm{~L}$, linear term significant at $P=0.01$. 
Table 2. Effect of two soil drench applications (13 May, 31 Aug. 1987) of paclobutrazol on crown density, leader caliper, and flower size of Tibouchina and Fuchsia standards.

\begin{tabular}{|c|c|c|c|c|c|c|c|c|c|c|}
\hline \multirow{3}{*}{$\begin{array}{l}\text { Paclobutrazol } \\
\text { (mg/pot) }\end{array}$} & \multirow{2}{*}{\multicolumn{2}{|c|}{$\begin{array}{c}\text { Branch } \\
\text { length } \\
(\mathrm{cm})\end{array}$}} & \multirow{2}{*}{\multicolumn{2}{|c|}{$\begin{array}{c}\text { No. } \\
\text { laterals }\end{array}$}} & \multirow{2}{*}{\multicolumn{2}{|c|}{$\begin{array}{c}\text { Crown } \\
\text { density }\end{array}$}} & \multirow{2}{*}{\multicolumn{2}{|c|}{$\begin{array}{c}\text { Leader } \\
\text { caliper } \\
\text { (cm) }\end{array}$}} & \multicolumn{2}{|c|}{ Length $(\mathrm{mm})$} \\
\hline & & & & & & & & & \multirow{2}{*}{$\frac{\text { Petal }}{\mathrm{T}}$} & \multirow{2}{*}{$\begin{array}{r}\text { Sepa } \\
F\end{array}$} \\
\hline & $\mathrm{T} 2^{\mathrm{z}}$ & $\mathrm{F} 1^{\mathrm{z}}$ & $\mathrm{T} 3$ & $\mathrm{~F} 2$ & $\mathrm{~T}$ & $\mathrm{~F}$ & $\mathrm{~T}$ & $\mathrm{~F}$ & & \\
\hline 0.000 & 20 & 12 & 36 & 22 & 11 & 28 & 1.03 & 0.97 . & 41 & 38 \\
\hline 0.125 & 19 & 12 & 33 & 29 & 12 & 28 & 0.93 & 1.06 & 49 & 38 \\
\hline 0.250 & 16 & 11 & 47 & 20 & 20 & 27 & 1.00 & 0.90 & 43 & 37 \\
\hline 0.500 & 11 & 11 & 31 & 14 & 34 & 17 & 0.89 & 0.86 & 43 & 36 \\
\hline Significance $^{x}$ & $\mathrm{~L}$ & NS & NS & $\mathrm{L}$ & $\mathrm{L}$ & NS & L & $\mathrm{L}$ & $\mathrm{Q}$ & NS \\
\hline
\end{tabular}

${ }^{z} \mathrm{~T}=$ Tibouchina, $\mathrm{F}=$ Fuchsia $; 1,2,3=$ primary, secondary, and tertiary branches, respectively.

- yTibouchina: number of tertiary laterals per meter of secondary branch; Fuchsia: number of secondary laterals per meter of primary branch.

${ }^{\times}$S, not significant; $\mathrm{L}$, linear term significant at $P=0.01 ; \mathrm{Q}$, quadratic term significant at $P=0.05$.

Table 3. Effect of one soil drench application (22 Mar. 1988) of chlormequat on Tibouchina height, branch length, number of laterals, crown density, and stem caliper.

\begin{tabular}{lccccc}
\hline \hline $\begin{array}{l}\text { Chlormequat } \\
\text { (mg/pot) }\end{array}$ & $\begin{array}{c}\text { Plant } \\
\text { ht } \\
(\mathrm{cm})\end{array}$ & $\begin{array}{c}\text { Branch } \\
\text { length } \\
(\mathrm{cm})\end{array}$ & $\begin{array}{c}\text { No. } \\
\text { laterals }\end{array}$ & $\begin{array}{c}\text { Crown } \\
\text { density }\end{array}$ & $\begin{array}{c}\text { Caliper } \\
\text { (cm) }\end{array}$ \\
\hline 0 & 139 & 66 & 8.3 & 0.13 & 1.79 \\
1000 & 124 & 53 & 9.5 & 0.19 & 1.75 \\
2000 & 119 & 43 & 8.1 & 0.23 & 1.74 \\
Significance & $*$ & $* *$ & NS & $*$ & Ns \\
\hline
\end{tabular}

${ }^{2}$ Number of tertiary laterals per meter of secondary branch.

NS,**** Linear term not significant at $P=0.05$ or significant at $P=0.05$ or 0.01 , respectively,

or by paclobutrazol in Fuchsia. Paclobutrazol did not affect the weight, number, or sepal size of Fuchsia flowers. The number of panicles m Tibouchina was not affected, although petals were longer at $0.125 \mathrm{mg} / \mathrm{pot}$ than at higher rates or in the controls (Table

The ability to produce Tibouchina standards with well-shaped crowns through the use of growth regulators may be appealing to parks and conservatories. There was less promise for the treatment of Fuchsia.

\section{Literature Cited}

Armitage, A.M. 1986. Chlormequat-induced early flowering of hybrid geranium: The influence of gibberellic acid. HortScience 21:116-118.

Goulston, G.H. and S.J. Shearing. 1985. Review of the effects of paclobutrazol on ornamental pot plants. Acta Hort. 167:339-349.

Hamza, A.M. and M.N.M. Helaly. 1983. Interaction between chlormequat (CCC) and gibber- ellin $\left(\mathrm{GA}_{3}\right)$ on growth, flowering and mineral constituents of some ornamental plants. Acts Hort. 137:197-203. -

Hentig v., V.U. 1985. Treatment of rarely cultivated pot-plants with growth regulators. Acta Hort. 167:309-317.

Kristensen, L.N. and E. Adriansen. 1988. Growth and flowering in Hebe $\times$ franciscana 'Variegate' treated with plant growth regulators. Scientia Hort. 36:139-149.

McDaniel, G.L. 1986. Comparison of paclobutrazol, flurprimidol, and tetcyclacis for controlling poinsettia height. HortScience 21:1161-1163.

Roberts, C.M. and G.W. Eaton. 1988. Response of Tibouchina to chlormequat, paclobutrazol, and fertilizer. HortScience 23:1082.

Shanks, J.B. 1980. Chemical dwarfing of several ornamental greenhouse" crops with PP333. Proc. 7th Annu. Meeting Plant Growth Regulator Working Group. Plant Growth Regulat. Soc. Amer. 1980:46-51.

Wainwright, H. and H.L. Irwin. 1987. The effects of paclobutrazol and pinching on antirrhinum flowering pot plants. J. Hort. Sci. 62:401-404.

Wilkinson, R.I. and D. Richards. 1987. Effects of paclobutrazol on growth and flowering of Bouvardia hamboldtii. HortScience 22:444-445. 